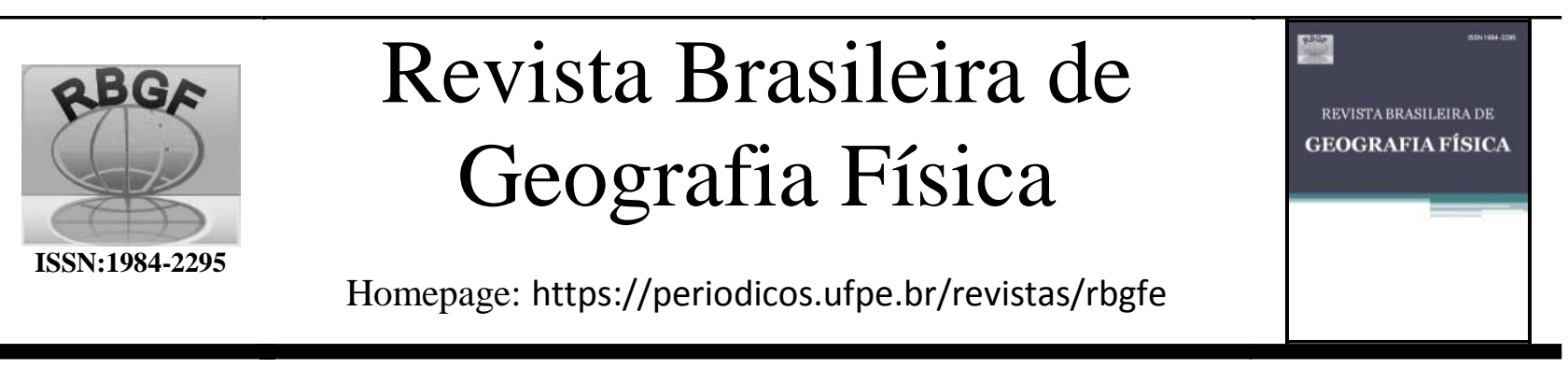

\title{
Analysis of flows in the Guaíba Hydrographic Region: Current variability and Trends due to Climate Change
}

\author{
Sabrina Antunes Vieira ${ }^{1}$, Daniela Muller de Quevedo² ${ }^{2}$ Katiucia Nascimento Adam ${ }^{3}$, Leonardo \\ Espínd ola Birlem ${ }^{4}$, Darlan Daniel Alves ${ }^{5}$, Daniela M. Migliavacca Osório ${ }^{6}$
}

\begin{abstract}
${ }^{1}$ Mestre e doutoranda em Qualidade Ambiental, Programa de Pós-Graduação em Qualidade Ambiental, Universidade Feevale, Novo Hamburgo, Brasil, e-mail: sazinha.93@gmail.com (autor correspondente). ${ }^{2}$ Dra. em Recursos Hídricos e Saneamento Ambiental, Professora do Programa de Pós-Graduação em Qualidade Ambiental, Universidade Feevale, Brasil, e-mail:daneilamq @feevale.br. ${ }^{3}$ Dra. em Recursos Hídricos e Saneamento Ambiental, Universidade Federal do Pará, Brasil, e-mail: katiucia@ufpa.br. ${ }^{4}$ Universidade Feevale, Brasil, e-mail: leonardobirlem@gmail.com. ${ }^{5}$ Doutor em Qualidade Ambiental, Universidade Feevale, Brasil, e-mail: darlandaniel@gmail.com. ${ }^{6}$ Doutora em Ecologia, Professora do Programa de Pós-Graduação em Qualidade Ambiental, UniversidadeFeevale, Brasil, e-mail: danielaos orio @ feevale.br.
\end{abstract}

Artigo recebido em 23/11/2020 e aceito em 19/04/2021

\section{A B S T R A C T}

Climate change has become a worldwide theme discussed in the last decades, mainly about the various expected impacts. Some research claims that some of these impacts are already occurring, such as the change in the rainfall regime, causing more frequent droughts and floods, an increase in sea levels, among others. Based on this, monitoring water resources to analyze possible changes in hydrological behavior is fundamental for the proper planning and management of these resources. Therefore, the objective of this research was to evaluate the flow behavior in the Guaíba hydrographic region over a period of 33 years and disturb the series based on expected trends due to climate changes to assess how the flows can be affected. For this purpose, data on maximum monthly flows for the period from 1985 to 2017 were obtained from ten fluviometric stations in the Guaíba hydrographic region, southern Brazil. These data were evaluated using descriptive statistics and permanence curves. Afterwards, the series were disturbed and evaluated again. Through the observation of the historical behavior of the flow it was noticed that many stations indicate changes in the temporal variation, with a tendency to increase the number of great magnitude flows, but, on the other hand, it is verified the temporal increase of minimum flows. The projected trends for the region indicate an increase in the volume of precipitation and in the flow of the rivers, however they tend to be more concentrated in short periods of time.

Keywords: Watersheds; permanence curves; climate change; trends; river flow.

\section{Análise de vazões na Região Hidrográfica do Guaíba: Variabilidade atual e Tendências devido às Mudanças Climáticas}

\section{RESUMO}

As mudanças climáticas tornaram-se um tema mundialmente discutido nas últimas décadas, principalmente levando-se em consideração os diversos impactos previstos decorrentes destas mudanças. Algumas pesquisas alegam que alguns destes impactos já estão ocorrendo, como a alteração no regime das chuvas, ocasionando secas e inundações mais frequentes, aumento nos níveis dos mares, dentre outros. Com base no exposto, percebe-se que realizar um monitoramento dos recursos hídricos para analisar possíveis alterações no comportamento hidrológico é fundamental para o adequado planejamento e gerenciamento destes recursos. Assim sendo, o objetivo desta pesquisa foi a valiar o comportamento das vazões na região hidrográfica do Guaíba em um período de 33 anos e, após, perturbar as séries com base nas tendências esperadas devido às mudanças climáticas para avaliar como as vazões desta região podem ser afetadas. Para tanto, foram obtidos dados de vazões máximas mensais para o período de 1985 a 2017 de dez estações fluviométricas da região hidrográfica do Guaíba, sul do Brasil. Estes dados foram avaliados utilizando-se estatística descritiva e curvas de permanência. Após, as séries foram perturbadas e foram novamente avaliadas. Através da observação do comportamento histórico da vazão percebeu-se que muitas estações indicam alterações na variação temporal, com tendência de aumento do número de vazões de grande magnitude, mas, por outro lado constata -se o aumento temporal de vazões mínimas. As tendências projetadas para a região indicam aumento no volume da precipitação e, consequentemente, na vazão dos rios, no entanto tendem a ser mais concentradas em curtos espaços de tempo.

Palavras-chave: Bacias hidrográficas; curvas de permanência; mudanças climáticas; tendências; vazão. 


\section{Introduction}

There are several consequences foreseen due to climate change, and a few changes have already been observed, such as the melting of the polar ice caps and the occurrence of more frequent extreme phenomena. According to Guha-Sapir, Hoyos and Below (2016), a survey carried out by the Research Center of Epidemiology and Disasters (CRED), in the year of 2015, 376 natural disasters were registered around the globe, of which a large amount refers to climatological and meteorological disasters, being considered the highest number of cases since 2005 .

Besides these consequences, the forecast leans to an increase in the average level of the seas (through the acceleration of the ice caps melting), more often occurrences of droughts, floods, storms, windstorms, extremely high temperatures, among others. The water resources will also be affected by the climate changes and, in this scenario, an increase of warm days, affecting the rainfall and the flow rate of rivers can be expected, which may increase the frequency of epidemics. Also, the foreseen scenarios indicate that lack of water in several regions may occur, which will bring many conflicts in order to access this resource (ANA, 2016; Herring et al., 2016).

In Brazil, the impact scenario of water resources may vary according to the region. According to some projections (Marengo, 2008; PBMC, 2013) there is a trend for an increase of precipitations in the southem region and a decrease in the northern and northeastern regions. On the other hand, according to Silva et al. (2020), there is a possible intensification in the regime of annual precipitation in most of the hydrographic regions of Brazil, except in the south and southeast regions. As for flow rates, changes were projected in a study by Milly et al. (2005) through a relative change of flow rates in rivers of South America for the periods of 1979-2000 and 2041-2060. The forecasts indicated increases up to $40 \%$ in the southern Brazil flow rates and a decrease up to $20 \%$ in the northeastern region.

In addition to climate change, other factors such as demographic pressure, disordered urban growth and lack of infrastructure and service investments contribute to the increase in hydric vulnerability in Brazil (Salviano et al., 2016).

Indirect consequences that can be mentioned are the increase in food prices (due to the losses that crops may suffer due to the greater occurrence of thunderstorms, changes in rainfall behavior), problemas in energy production and population health risks (Alcântara et al., 2020). Thus, it is clear that the low-income population may face even more difficulty in accessing food, resulting in a serious social impact (De Paulo and Mendes, 2014).

Some works (Mcnamara, 2008; Crook and Short, 2014) are showing another consequence that may occur increasingly significantly due to climate change, which is the likelihood of intense migration, giving rise to the term "environmental refugees". An example of this is stream-dwelling populations, which are of ten polluted due to poor sanitation. With the increase in intensity and volume of rainfall, these areas may suffer flooding, increasing the health risk due to the presence of pathogenic organisms in the water (Artaxo, 2020).

Given this, the trend analysis allows observing changes in the behavior of certain hydrological variables, which allows the identification of regions with more significant changes. The identification of these regions allows us to estimate the possible damage to the changes in socio-economic activities, helping decisionmakers in formulating public policies. Thus, public policies become essential in reducing and mitigating impacts. An example of this is policies aimed at reducing greenhouse gas emissions, considering this new climate profile. Only with the formulation and implementation of these policies, it will be possible to conserve the quality of life of populations and the ecosystem as a whole (Martins and Ferreira, 2011; Salviano et al., 2016; IPCC, 2018).

When we talk about water resources, it is essential to constantly monitor watersheds to assess possible changes in their hydrological behavior, as climate change can have major impacts on water resources (Milly et al., 2005; Marengo, 2008; Franco et al., 2019), which may affect both socio-economic activities and local fauna and flora. The monitoring of watersheds can be done by collecting hydrometeorological data, which can be used in studies for different applications, such as the hydropower sector, basic sanitation, public and industrial supply, irrigation and drainage, livestock, planning, weather forecasting, climate changes and environmental impacts (Salgueiro and Montenegro, 2008). In addition, they are also extremely important for the design of projects such as containment dams, terraces and containment basins, urban drainage, bridges, canals, among others (Cavalcante and Silans, 2012).

Studies about the river flow behavior are essential, since their knowledge makes possible to determine appropriate values of reference flows for water availability of a given region, being this information fundamental for decision making and public policy formulation in the management of 
water resources (Mello et al., 2010; Moreira and Silva, 2013; Lima and Junior, 2018).

With changes in river flow rates there may be an increase in the number of floods, and the floods are the type of disaster that has the largest number of events, with many people affected and the greatest economic losses (da Silva et al., 2016; Sausen et al., 2018).

Based on this and considering that river flow rates can be affected by climate changes, the main objective of this research was to evaluate the historical behavior (over a period of 33 years) of river flows in the Guaíba hydrographic region and to assess how the flows of this region can be affected by climate change disturbing the time series based on expected trends, which can enables managers to better manage the region's water resources.

As with the studies presented, it is expected to find changes in the flow behavior, with a possible increase in the quantity and intensity of extreme events in this region related to this variable.

\section{Methodology}

Study Area

The state of Rio Grande do Sul is divided into 24 watersheds, which are distributed in three Hydrographic Regions, namely: Uruguai River Hydrographic Region, comprising the drainage areas of the Uruguai river and Negro river and covering about $57 \%$ of the total area of the state; Lake Guaíba Hydrographic Region, including the drainage areas of Guaíba and covering about $30 \%$ of the total area; and Coastal Hydrographic Region, which covers the other drainage areas of water resources not included in the other Regions and representing $13 \%$ of the total area (Sausen et al., 2018).

In this study data were acquired from the Guaíba Hydrographic Region, which is characterized by the large industrial and urban concentration, being the most densely populated in the state, besides presenting diversified activities such as industries, agriculture, agribusiness, among others. It is located in the northeastern region of the State, between the $28^{\circ} \mathrm{S}$ and $31^{\circ} \mathrm{S}$ parallels and the $50^{\circ} \mathrm{W}$ and $54^{\circ} \mathrm{W}$ meridians, with a total area of $84.763,54 \mathrm{~km}^{2}$ and serving a population of $5,869,265$ inhabitants, representing $61 \%$ of the total population of the State. The location of this hydrographic region as well as the fluviometric stations used is shown in Figure 1.

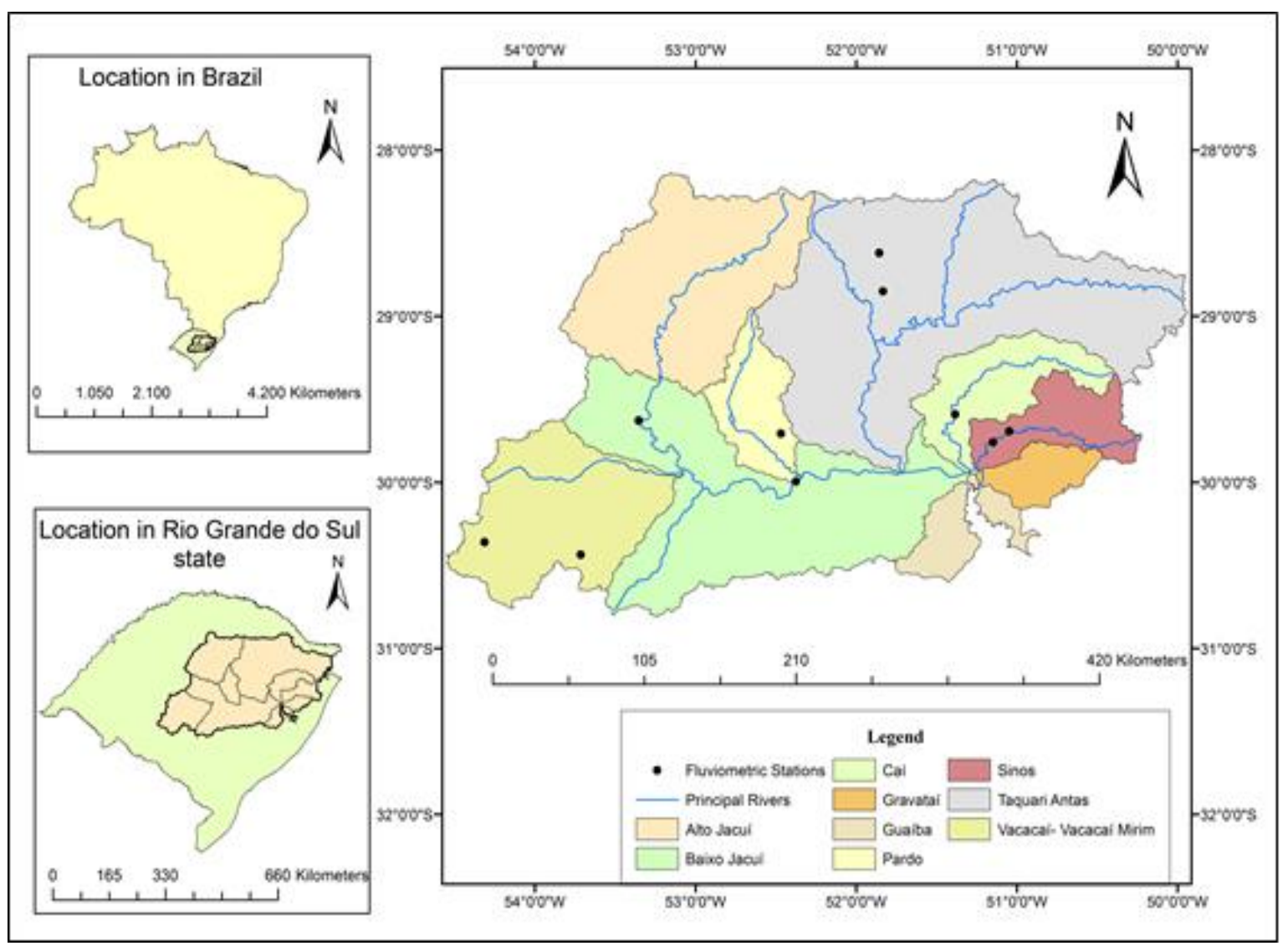

Figure 1. Location of Fluviometric Stations in Guaíba hydrographic region. 
Materials and Methods

The methodology consisted of the following steps:

a) Acquisition of data:

The maximum monthly flow data of the watersheds present in the Guaiba Hydrographic Region were obtained through the Hidroweb system, provided by the National Water Agency (ANA) for a period of 33 years (1985 to 2017).
The World Meteorological Organization recommends that, for climate studies, a series of at least 30 years be used (WMO, 2007). The data acquired were those available at the monitoring stations throughout the watersheds for the intended study time, which are listed in Table 1 . It is noted that no station was used in three watersheds in this hidrografic region, as no data were available for the intended period, or the data had many flaws, which makes the study unfeasible.

\begin{tabular}{|c|c|c|c|c|c|}
\hline Code & Watershed & County & Latitude S & Longitude W & $\begin{array}{l}\text { Altitude } \\
\text { (m) }\end{array}$ \\
\hline 86480000 & Taquari-Antas & Casca & $28^{\circ} 37^{\prime} 8.04^{\prime \prime}$ & $51^{\circ} 51^{\prime} 20.88^{\prime \prime}$ & 480.0 \\
\hline 86500000 & Taquari-Antas & Guaporé & $28^{\circ} 50^{\prime} 56.04 "$ & $51^{\circ} 49^{\prime} 57.00^{\prime \prime}$ & 260.0 \\
\hline 85400000 & Baixo Jacuí & Dona Francisca & $29^{\circ} 37^{\prime} 36.84^{\prime \prime}$ & $53^{\circ} 21^{\prime} 10.08^{\prime \prime}$ & 32.44 \\
\hline 85900000 & Baixo Jacuí & Rio Pardo & $29^{\circ} 59^{\prime} 42.00^{\prime \prime}$ & $52^{\circ} 22^{\prime} 32.16^{\prime \prime}$ & 2.38 \\
\hline 85470000 & $\begin{array}{c}\text { Vacacaí-Vacacaí } \\
\text { Mirim }\end{array}$ & São Gabriel & $30^{\circ} 21^{\prime} 34.92^{\prime \prime}$ & $54^{\circ} 18^{\prime} 47.88^{\prime \prime}$ & 81.93 \\
\hline 85610000 & $\begin{array}{c}\text { Vacacaí-Vacacaí } \\
\text { Mirim }\end{array}$ & São Sepé & $30^{\circ} 26^{\prime} 8.16^{\prime \prime}$ & $53^{\circ} 42^{\prime} 50.04^{\prime \prime}$ & 219.5 \\
\hline 85830000 & Pardo & Santa Cruz do Sul & $29^{\circ} 42^{\prime} 21.96^{\prime \prime}$ & $52^{\circ} 28^{\prime} 5.16^{\prime \prime}$ & 23.97 \\
\hline 87170000 & Caí & São Sebastião do Caí & $29^{\circ} 35^{\prime} 24.00^{\prime \prime}$ & $51^{\circ} 23^{\prime} 0.00^{\prime \prime}$ & -0.76 \\
\hline 87380000 & Sinos & Campo Bom & $29^{\circ} 41^{\prime} 30.12^{\prime \prime}$ & $51^{\circ} 2^{\prime} 45.96^{\prime \prime}$ & 2.11 \\
\hline 87382000 & Sinos & São Leopoldo & $29^{\circ} 45^{\prime} 32.04^{\prime \prime}$ & $51^{\circ} 8^{\prime} 53.88^{\prime \prime}$ & -0.42 \\
\hline
\end{tabular}

Table 1. Description of the fluviometric stations used.

b) River flows analysis:

After having complete series, the data variability was analyzed through the mean, variance, coefficient of variation and $F$ test using Excel sof tware. Data were grouped by periods, the first period from 1985 to 2004 and the second from 2005 to 2017. This division was made because, according Vieira et al. (2018), was identified changes in the flow patterns of the Rio dos Sinos watershed, which is part of the Guaiba hydrographic region, mainly after 2005, through the observation of graphs and analysis of variance for previous and later data than 2005. With this division it becomes possible to identify if there were significant differences in the behavior of the flow series in the last years when compared to previous years.

Finally, the river flow permanence curves were elaborated for both periods. According to Vogel and Fennessey (1994) these curves represent, graphically, the relationship between the magnitude and the frequency with which the flows are equaled or exceeded in a certain period of time, demonstrating the flow variability over time.

c) Series disturbance:

For this stage we based on published studies that predict changes in the river flow of the region under study, so then disturb the series considering projections until the year 2040 .

According to a study published by the Strategic Affairs Secretariat in 2015 (Brazil, 2015), the flow trend in Rio Grande do Sul, considering the IPCC RCP 4.5 scenario (intermediate scenario) and using the regional model of ETA/MIROC5 projection, is an increase of $10 \%$ to $30 \%$ by the year 2040. Based on this, the series were disturbed and the data were presented as monthly averaged graphs to indicate a possible scenario of flow rates in the Guaiba hydrographic region over the next 20 years.

\section{Results and discussion}

Temporal Variation

After the acquisition of data and the application of statistical analysis, the values presented in Table 2 were obtained. The significance of 0.05 was employed in the $\mathrm{F}$ test.

By analyzing the Table 2, it is realized that, in the same watershed, the water flow may show distinct behaviors, as the stations of Guaporé and Casca, which belong to the watershed of Taquari-Antas river, where the Guaporé station 
presented significant differences in the variance analysis between the two periods.

Among the ten used stations, four of them present significant differences in the behavior of flow rate among the evaluated periods (Guaporé, Santa Cruz do Sul, Campo Bom and São Leopoldo). It is important to emphasize that the ideal, when it is discussed about climate changes, would be to evaluate the difference among periods larger than the used ones, however the lack of available data makes it difficult to carry out a thorough analysis.
Besides the statistical analysis, in order to evaluate the possible alterations on the behavior of the flow rate, it is also important the visualization of the permanence curves, since many times, when discussing the use of theses data to hydrological projects, the data obtained through these curves are fundamental, such as the minimum (at $10 \%$ of time - Q10) and maximum (90\% of time - Q90) reference flows. Figures 2, 3, 4, 5, 6 and 7 will show the residence curves for each season separated by watersheds.

\begin{tabular}{|c|c|c|c|c|c|}
\hline Station & Period & Average & Variance & CV (\%) & $P(F<=f)$ \\
\hline \multirow{2}{*}{ Casca } & $1985-2004$ & 173,31 & 36358,53 & 110,02 & \multirow{2}{*}{0,0514} \\
\hline & 2005-2017 & 185,39 & 45978,35 & 115,66 & \\
\hline \multirow{2}{*}{ Guaporé } & $1985-2004$ & 278,91 & 127398,63 & 127,98 & \multirow{2}{*}{$0,0163^{*}$} \\
\hline & $2005-2017$ & 313,43 & 173281,71 & 132,81 & \\
\hline \multirow{2}{*}{$\begin{array}{c}\text { Dona } \\
\text { Francisca }\end{array}$} & $1985-2004$ & 1080,82 & 685063,59 & 76,58 & \multirow{2}{*}{0,4076} \\
\hline & $2005-2017$ & 954,96 & 707743,69 & 88,10 & \\
\hline \multirow{2}{*}{ Rio Pardo } & $1985-2004$ & 1859,76 & 1630873,70 & 68,67 & \multirow{2}{*}{0,2653} \\
\hline & $2005-2017$ & 1809,73 & 1784070,73 & 73,81 & \\
\hline \multirow{2}{*}{ São Gabriel } & $1985-2004$ & 92,32 & 12399,26 & 120,62 & \multirow{2}{*}{0,0582} \\
\hline & $2005-2017$ & 68,31 & 9822,29 & 145,09 & \\
\hline \multirow{2}{*}{ São Sepé } & $1985-2004$ & 12,86 & 330,58 & 141,39 & \multirow{2}{*}{0,2198} \\
\hline & $2005-2017$ & 11,83 & 369,37 & 162,48 & \\
\hline \multirow{2}{*}{$\begin{array}{c}\text { Santa Cruz do } \\
\text { Sul }\end{array}$} & $1985-2004$ & 95,41 & 4854,82 & 73,02 & \multirow{2}{*}{$0,0413 *$} \\
\hline & $2005-2017$ & 82,51 & 6258,99 & 95,89 & \\
\hline \multirow{2}{*}{$\begin{array}{c}\text { São Sebastião } \\
\text { do Caí }\end{array}$} & $1985-2004$ & 288,98 & 96363,47 & 107,42 & \multirow{2}{*}{0,0635} \\
\hline & $2005-2017$ & 295,21 & 120055,50 & 117,37 & \\
\hline \multirow{2}{*}{ Campo Bom } & $1985-2004$ & 177,75 & 13361,07 & 65,03 & \multirow{2}{*}{$0,0008 *$} \\
\hline & 2005-2017 & 184,99 & 21017,72 & 78,37 & \\
\hline \multirow{2}{*}{ São Leopoldo } & $1985-2004$ & 185,34 & 16962,66 & 70,27 & \multirow{2}{*}{$3,762 \mathrm{e}-7 *$} \\
\hline & $2005-2017$ & 201,63 & 34508,84 & 92,13 & \\
\hline
\end{tabular}

Table 2. Statistical analysis for periods before and after 2005 .

$\mathrm{CV}$ - coefficient of variation * statistically significant

Figure 2 shows the permanence curves for the stations present in the watershed of Taquari-
Antas river, where the stations presented different behaviors among them.

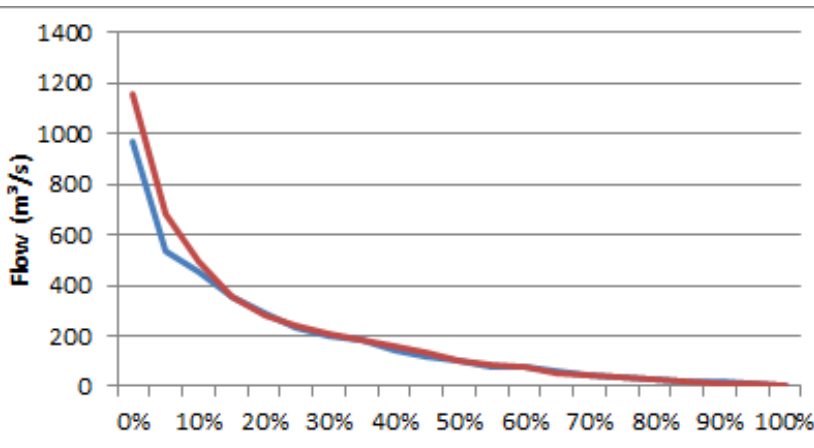

a)

-1985-2004 2005-2017

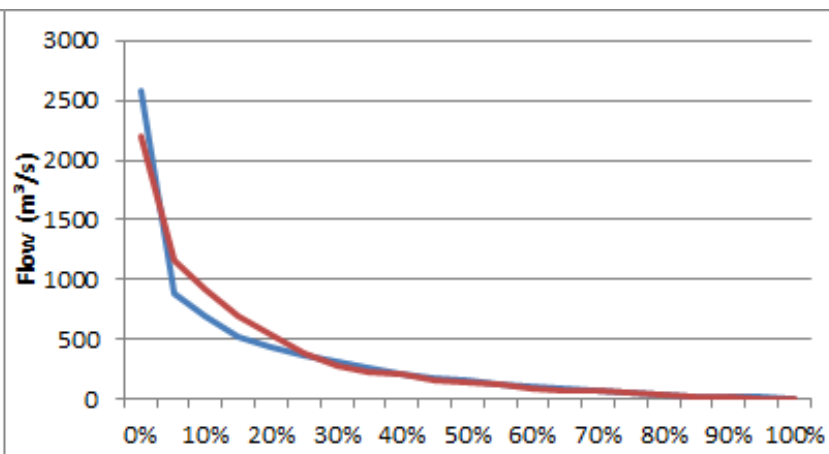

b)

Figure 2. Flow permanence curves for the Casca (a) and Guaporé (b) stations of the Taquari-Antas watershed.

Vieira., S., A., Quevedo., D., M., Adam., K., N Birlem., L.,E., Alves., D., D., Osório., D., M., M. 
At Casca station, it is noticed a difference in flow behavior only when discussing about flow rates below $20 \%$ of the time, and in these cases, the last years presented values above those occurred until 2004. In the other hand, at Guaporé station, which presented a statistically significant difference, the data presented a larger difference between $10 \%$ to $30 \%$ of the time, also with values above those occurred until the year 2004 .

Regarding the Baixo Jacuí watershed, Figure 3, although none of the two stations show significant differences in the statistical test, a distinct behavior is observed between the two analyzed periods, especially in Dona Francisca station. In the case of this station, unlike what was found in the Taquari-Antas river watershed, the flow values for the period from 2005 to 2017 were lower than the period from 1985 to 2004 in approximately $10 \%$ to $60 \%$ of the time.

For the station located in Rio Pardo, both years after and before 2005, the flow presents a similar behavior, with a small distinction between the permanence curves, both for smaller (up to $15 \%$ of time) and larger values (from $20 \%$ to $70 \%$ of the time).
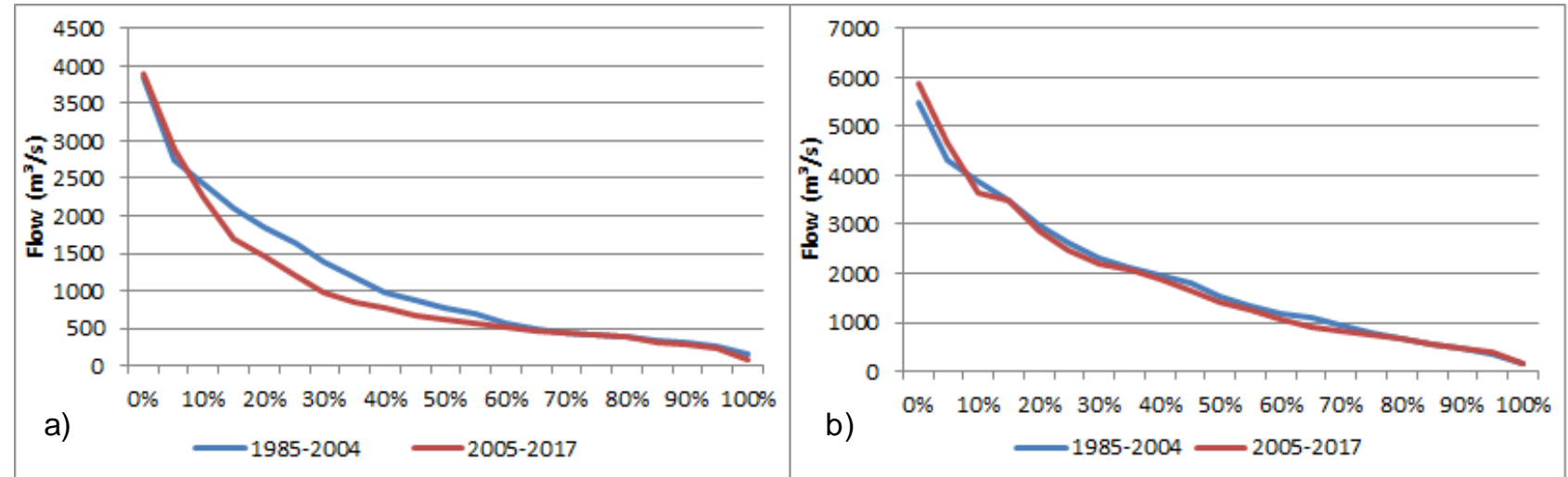

Figure 3. Flow permanence curves for the Dona Francisca (a) and Rio Pardo (b) stations of the Baixo Jacuí watershed.

In the stations present in the watershed of Vacacaí-Vacacaí Mirim river (Figure 4), the permanence curves presented lower values in the last 13 years compared to the years prior to 2005 . However, while the São Gabriel station presented higher values up to $5 \%$ of the time and smaller between $10 \%$ to $60 \%$ of the time, the São Sepé station presented smaller values only between $10 \%$ to $30 \%$ of the time.
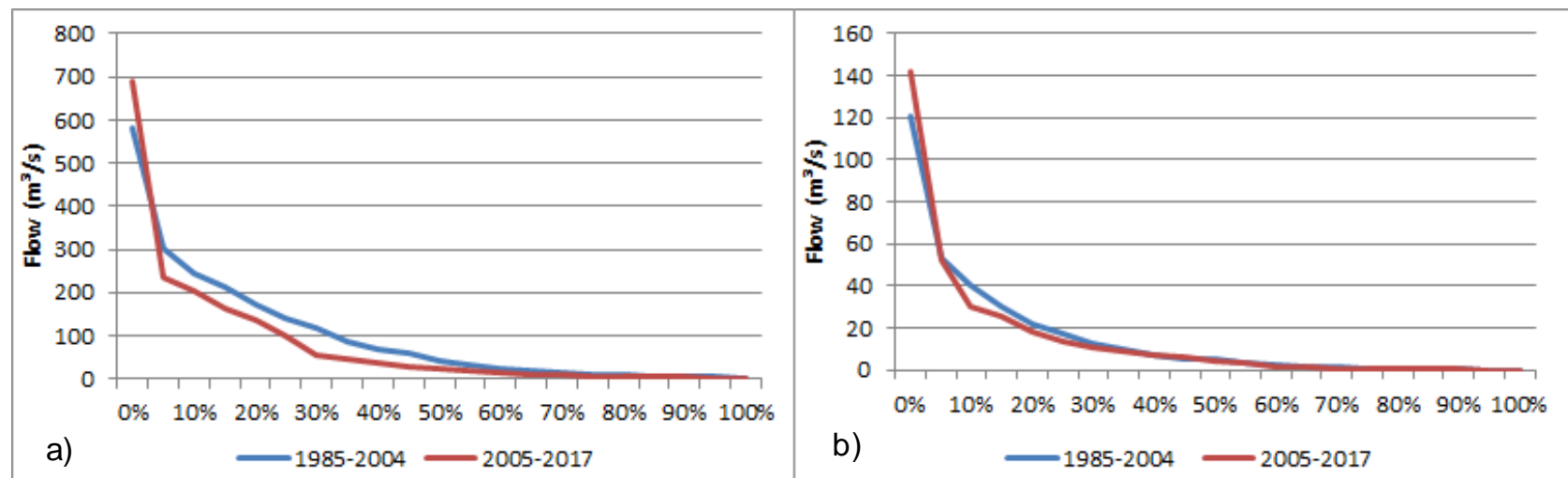

Figure 4. Flow permanence curves for the São Gabriel (a) and São Sepé (b) stations of the Vacacaí-Vacacaí Mirim watershed.

In the Pardo river watershed, represented in this study by the Santa Cruz do Sul station, the permanence curve (Figure 5) showed a very

distinct behavior between the two periods, besides presenting a statistically significant difference. 


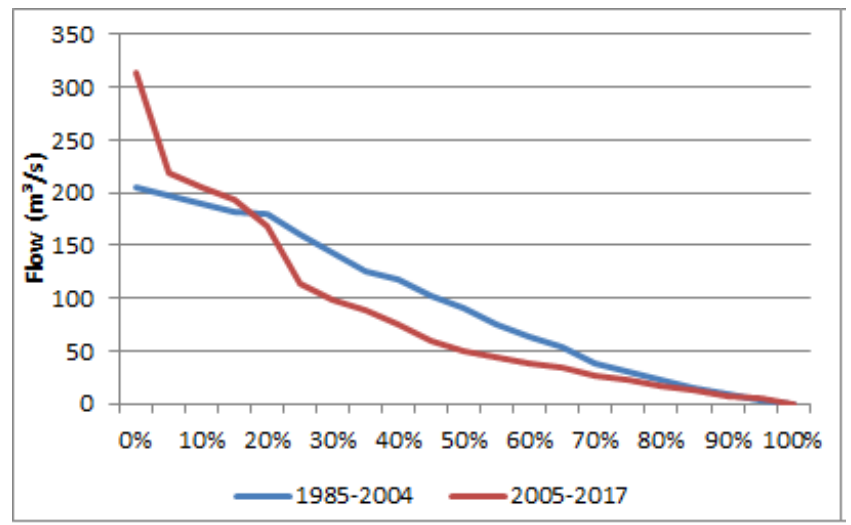

Figure 5. Flow permanence curves for the Santa Cruz do Sul station of the Pardo river watershed.

In this permanence curve it is possible to verify that, in $0 \%$ to $20 \%$ of the time, the flow increased while, in $25 \%$ to $85 \%$ of the time, the flow decreased in the period after 2005, when compared with the flow values of the period from 1985 to 2004. This may mean that the flow extremes of this station may be occurring more frequently, both of which are larger and smaller flows.

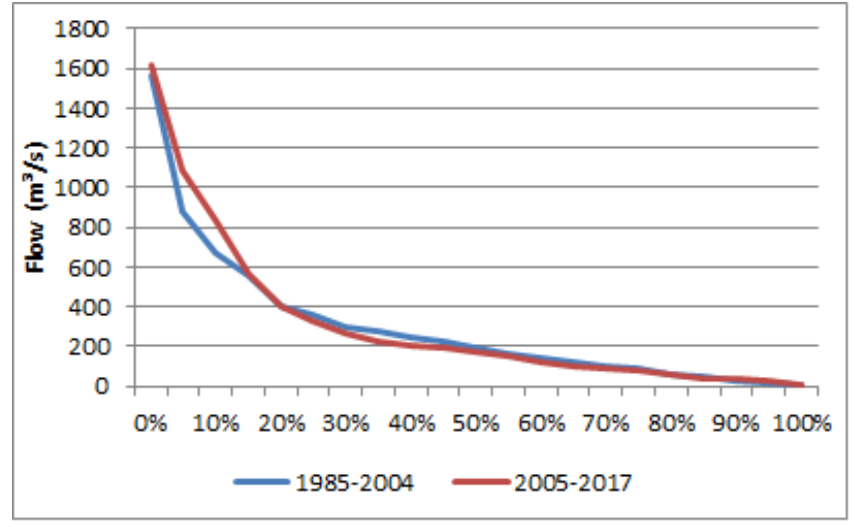

Figure 6. Flow permanence curves for the São Sebastião do Caí station of the Caí river watershed.

Finally, at Campo Bom and São Leopoldo stations, belonging to the Sinos river watershed, there are very distinct curves between the two
In Figure 6, which shows the permanence curves for the watershed of Caí river, in this study represented by the São Sebastião do Caí station, a difference is observed mainly for flows up to $20 \%$ of the time, with higher values for the period, as well as a slight reduction in the period from $20 \%$ to $55 \%$ of the time.

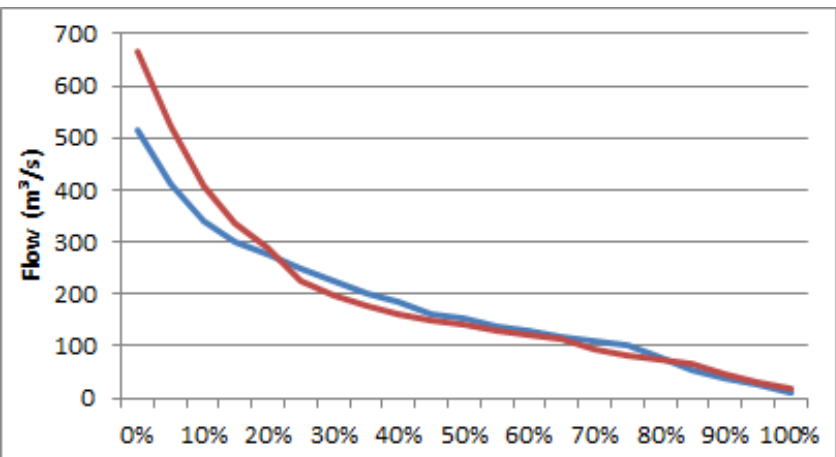

a)

$\longrightarrow$ 1985-2004 $2005-2017$

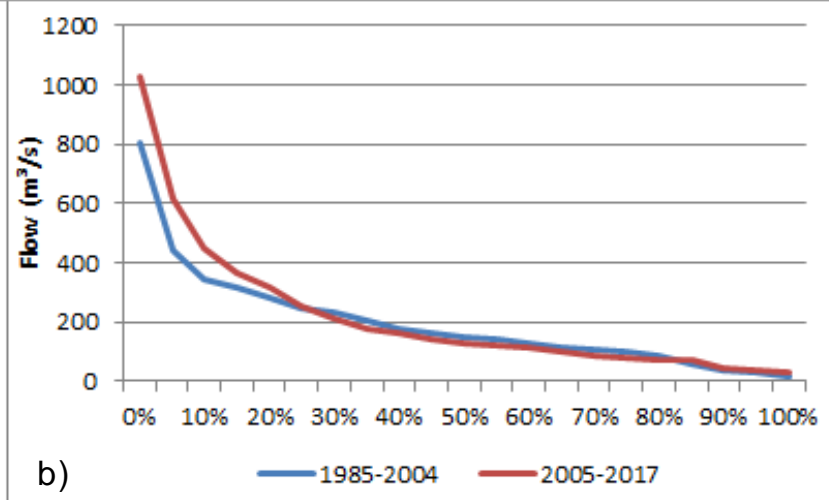

Figure 7. Flow permanence curves for the Campo Bom (a) and São Leopoldo (b) stations of the Sinos river watershed.

Vieira., S., A., Quevedo., D., M., Adam., K., N Birlem., L.,E., Alves., D., D., Osório., D., M., M. 
By analyzing the flow permanence curves of these stations, it is observed that from 2005 onwards, the flow rates below Q20 presented the greatest alteration, increasing in relation to previous years, while in certain time periods, as in Q75, the flow presented lower values.

This may be an indicative that flow extremes may occur more frequently in this region, with high flow values at shorter time intervals, but also with lower flow values at longer time intervals, especially at the Campo Bom station.

In general, with some exceptions in certain seasons (São Sebastião do Caí, São Sepé, Rio Pardo and Casca), it is clear that the distinct behavior between the periods before and after 2005 observed by Vieira et al. (2018) in the Sinos River watershed is also repeated in other stations in the Guaíba Hydrographic Region, such as in the Pardo, Vacacaí - Vacacaí Mirim, Baixo Jacuí and Taquari-Antas river watershed stations, with changes in the flow behavior in recent years, some even already showing significant differences, even in an observation of only 33 years of data, indicating, perhaps, more frequent extreme events, with changes in both the maximum and minimum flow rates.

Other studies have shown similar behavior. According to Marengo (2001), the Paraná River watershed, which drains the southern states of Brazil and part of Paraguay, has shown a significant increase in flow in recent decades, with an increase of approximately $15 \%$ since the 1960 s, an increase consistent with the increasing precipitation values observed in this watershed. Schuster et al. (2019), analysing the variation in water availability of basins within the Patos Lagoon contribution area, verified a tendency of increase of the average flows in the simulated basin.

The differences found among watersheds in the same region, and even among stations in the same watersheds, can be explained by factors such as population growth, changes in land use and occupation, and water uses.

\section{Trend Analysis}

After the historical analysis of the series and taking into account the trend of increased flow in the Rio Grande do Sul watersheds, with anomalies of increase between $10 \%$ and $30 \%$ until the year 2040, according to projections published by the Strategic Affairs Secretariat (SAE - Brazil, 2015), the series disturbance was considered by these projections. Results will be presented as monthly averages for the two historic periods (1985-2004 and 2005-2017) and for two projections, one with a $10 \%$ increase in flow and another with a $30 \%$ increase based on the acquired historical series. Figure 8 presents the results for all stations.

Looking at Figure 8 it is clear that, in all stations, there are months when the river flow may present a reduction (especially the period between April and June for most stations), while in others it may present even higher flows than projected (like September and October), especially when we observe the behavior of the averages from 2005 to 2017. Even when comparing the projections for some stations, these values may be below or well above expectations in some months.

Teixeira et al. (2020) verified presence of trends, both increase and decrease, in the series of monthly precipitation, minimum and maximum monthly streamflow, for the Juquiá river basin, São Paulo, as well as growth tendency in the series of minimum monthly streamflow.

In Rio Grande do Sul, a study by Tejadas et al. (2016) identified changes in the average annual river flow with an increase of $2.86 \%$ and $2.48 \%$ in scenarios A2 (the most pessimistic) and B2 (intermediate scenario) considering a near horizon, and $16.94 \%$ and $11.83 \%$ considering a long term.

These data demonstrate the importance of conducting studies that assess both a watershed's historical series and those seeking future projections of hydrological data, as current water resource management practices are unlikely to be sufficient to reduce the impacts that changes climate change can cause on water resources, especially with regard to water supply, flood and flood risks, health, energy, among others (Kundzewicz et al., 2007; Dalagnol et al., 2017). 


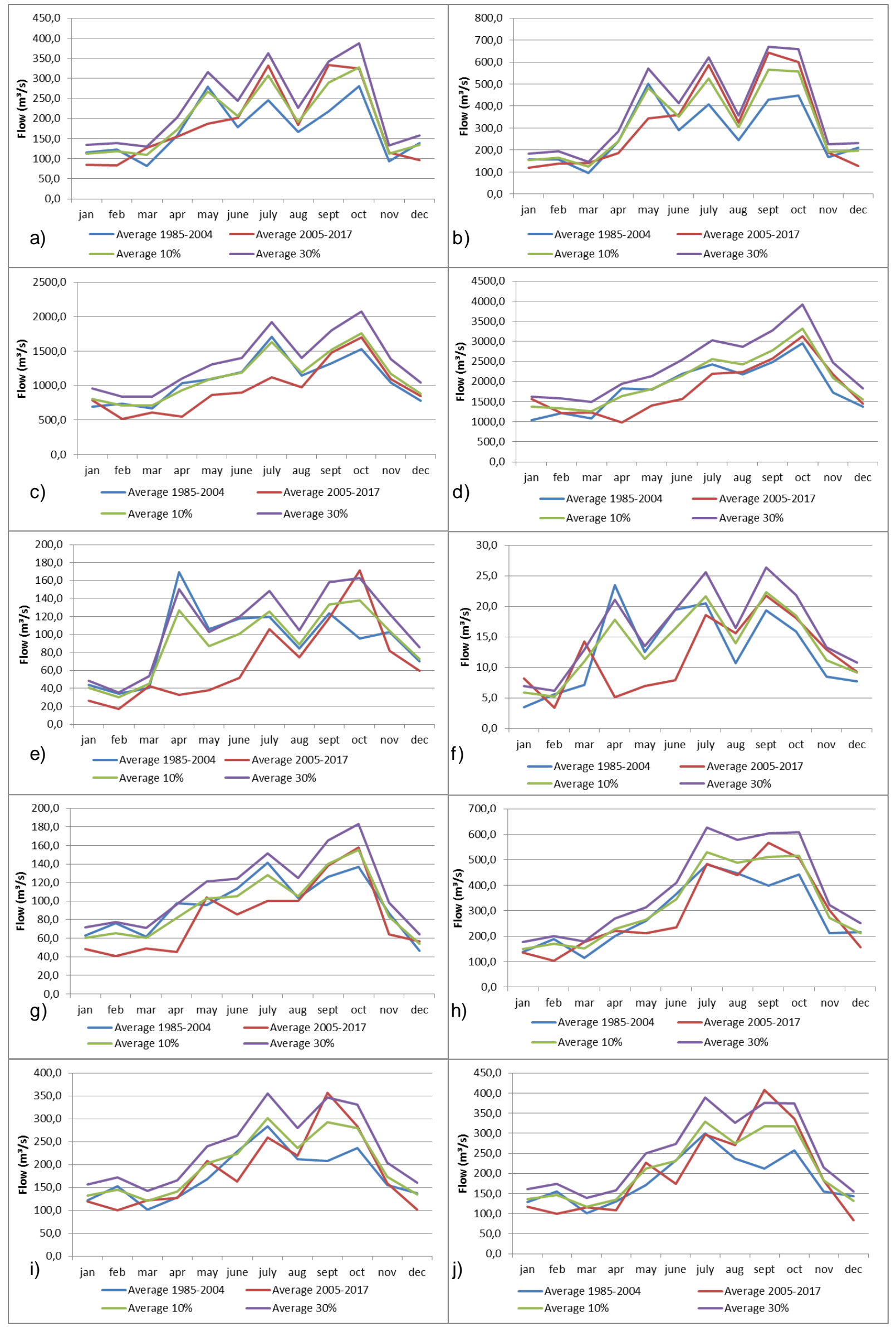

Figure 8. Monthly averages for the periods 1985-2004, 2005-2017 and the 10\% and 30\% increase projections for the Casca(a), Guaporé(b), Dona Francisca(c), Rio Pardo(d), São Gabriel(e), São Sepé(f), Santa Cruz do Sul(g), São Sebastião do Caí(h), Campo Bom(i) e São Leopoldo(j) stations.

Vieira., S., A., Quevedo., D., M., Adam., K., N Birlem., L.,E., Alves., D., D., Osório., D., M., M. 
As some data from this study have shown, trends indicate that there may be both a reduction in river flow in some months and an increase in others. Thus, studies on climate and water resources may contribute to the formulation and implementation of public policies aimed at minimizing these impacts, considering that this sector needs improvement in its methods and practices to cope with the changes that may come, in which according to Milly et al. (2008), we can no longer consider hydrological variables as stationary.

\section{Conclusions}

By observing the historical behavior of the river flow in several stations of the Guaiba hydrographic region, it was noticed that many stations indicate changes in the temporal variation, with a tendency to increase the river flow, but also, through the permanence curves, the flow decrease in certain time periods. This may indicate that more frequent extreme events are already occurring in these watersheds.

Projected trends for the region indicate exactly this, with projected increases in river flow volume, however with extreme periods such as floods and droughts. This demonstrates the importance of conducting this monitoring of hydrological variables in water resources, enabling proper management of watersheds and also assisting decision makers in formulating public policies appropriate to each location.

As for the river flow monitoring stations present in this hydrographic region, there is a lack of data in the vast majority, with few stations having complete series of more than 30 years. Most of the stations found had only recent data, or data with many failures, which makes a hydroclimatic study difficult.

\section{Acknowledgments}

This study was financed in part by the Coordenação de Aperfeiçoamento de Pessoal de Nível Superior - Brasil (CAPES).

\section{References}

Alcântara, L. R. P. de, da Silva, M. E. R., dos Santos Neto, S. M., Lafayette, F. B., Coutinho, A. P., Montenegro, S. M. G. L., Antonino, A. C. D., 2020. Climate change and trends of the rainfall of the city of Recife. Research, Society and Development, 9(3), e178932583. https://doi.org/10.33448/rsd-v9i3.2583

ANA- Agência Nacional das Águas, 2016. Mudanças Climáticas e Recursos Hídricos: avaliações e diretrizes para adaptação. Brasília: ANA, GGES.

Artaxo, P., 2020. As três emergências que nossa sociedade enfrenta: saúde, biodiversidade e mudanças climáticas. Estud. av. 34(100). DOI: 10.1590/s0103-4014.2020.34100.005.

Brasil, Secretaria de Assuntos Estratégicos - SAE, 2015. Brasil 2040: cenários e alternativas de adaptação à mudança do clima. Brasília, 62 p. Disponível em: <http://www.sae.gov.br/wpcontent/uploads/BRASIL-2040-Resumo-

Executivo.pdf $>$.

Cavalcante, A.L., Silans, A.M.B.P., 2012. Modelo estocástico de desagregação da chuva diária em Eventos sub-diários para a região litorânea do Nordeste. Revista Brasileira de Recursos Hídricos 17(3), 39-49.

Crook, M., Short, D., 2014. Lemkin and the genocide-ecocide nexus. The International Journal of Human Rights 18(3), 298-319.

Dalagnol, R., Borma, L. de S., Mateus, P., Rodriguez, D. A., 2017. Assessment of climate change impacts on water resources of the Purus Basin in the southwestern Amazon. Acta Amazonica, 47(3), 213-226.

Da Silva, P. V. R. M., Junior, R. A. F. C. e de Noronha, G. C., 2017. Mapeamento e análise de risco de inundação da Bacia do Rio Paraîba/AL: estudo de caso. Sistemas \& Gestão, 11(4), p. 431-443. doi: 10.20985/19805160.2016.v11n4.1143.

De Paulo, C.M., Mendes, A.C., 2014. A Presença da Ética nas Políticas Mundiais de Mudanças Climáticas. Revista Gestão \& Políticas Públicas 4(1), 191-207.

Franco, V., De Souza, E. B., Da Costa, C. P. W., Batista, D., Azevedo, F. T. M., 2019. Prognóstico sazonal da precipitação pluviométrica para o verão e outono austral da Amazônia Oriental. Revista Brasileira de Geografia Física, 12(01), 057-070.

Guha-Sapir, D., Hoyois, P., Below, R., 2016. Annual Disaster Statistical Review 2015: The Numbers and Trends. Brussels, CRED.

Herring, S.C., Hoell, A., Hoerling, M.P., Kossin, J.P., Schreck, III C.J., Stott, P.A., 2016. Explaining Extreme Events of 2015 from a Climate Perspective. American Meteorological Society 97(12), S1-S145.

IPCC - Intergovernmental Panel on Climate Change, 2018. Summary for Policymakers. In: Global Warming of $1.5^{\circ} \mathrm{C}$. An IPCC Special Report on the impacts of global warming of $1.5^{\circ} \mathrm{C}$ above pre-industrial levels and related global greenhouse gas emission pathways, in the context of strengthening the global response to the threat of climate change, sustainable 
development, and efforts to eradicate poverty [Masson-Delmotte, V., P. Zhai, H.-O. Pörtner, D. Roberts, J. Skea, P.R. Shukla, A. Pirani, W. Moufouma-Okia, C. Péan, R. Pidcock, S. Connors, J.B.R. Matthews, Y. Chen, X. Zhou, M.I. Gomis, E. Lonnoy, Maycock, M. Tignor, and T. Waterfield (eds.)]. World Meteorological Organization, Geneva, Switzerland, 32 p.

Kundzewicz, Z.W., Mata, L.J., Arnell, N.W., Döll, P., Kabat, P., Jiménez, B., Miller, K.A., Oki, T., Sen, Z., Shiklomanov, I.A., 2007. Freshwater resources and their management. In: Climate Change 2007: Impacts, Adaptation and Vulnerability. Contribution of Working Group II to the Fourth Assessment Report of the Intergovemmental Panel on Climate Change, M.L. Parry, O.F. Canziani, J.P. Palutikof, P.J. van der Linden and C.E. Hanson, Eds., Cambridge University Press, Cambridge, UK, pp. 173-210.

Lima, M.N.C.; Júnior, J.C.A., 2018. Análise da relação chuva-vazão na bacia hidrográfica do Rio Jucu-Braço Norte (ES). Revista Espaço Acadêmico 8(2), 97-112.

Marengo, J.A., 2001. Mudanças climáticas globais e regionais: avaliação do clima atual do Brasil e projeções de cenários climáticos do futuro. Revista Brasileira de Meteorologia 16(1), 01 18.

Marengo, J.A., 2008. Água e mudanças Climáticas. Estud. av. 22(63), São Paulo. Disponível em: <http://dx.doi.org/10.1590/S010340142008000200006>.

Martins, R.D., Ferreira, L.C., 2011. Uma revisão crítica sobre cidades e mudança climática: vinho velho em garrafa nova ou um novo paradigma de ação para a governança local?. RAP, Rio de Janeiro, 45(3), 611-41.

McNamara, K.E., 2008. Pragmatic Discourses and Alternative Resistance - Responses to Climate Change in the Pacific. Graduate Joumal of Asia-Pacific Studies 6(2), 33-54.

Mello, C.R., Viola, M.R., Beskow, S., 2010. Vazões máximas e mínimas para bacias hidrográficas da região Alto Rio Grande, MG. Ciênc. agrotec. 34(2), 494-502.

Milly, P.C.D., Dunne, K.A., Vecchia, A.V., 2005. Global pattem of trends in streamflow and water availability in a changing climate. Nature 438, 347-50.

Milly, P.C.D., Betancourt, J., Falkenmark, M., Hirsch, R.M., Kundzewicz, Z.W., Lettenmaier, D.P., Stouffer, R.J., 2008. Stationarity Is Dead: Whither Water Management?. Science 319, 573-585.
Moreira, M.C., Silva, D.D., 2013. Análise de Métodos para Estimativa das Vazões da Bacia do Rio Paraopeba. Revista Brasileira de Recursos Hídricos 19(2), 313-324.

PBMC. Painel Brasileiro de Mudanças Climáticas, 2013. Contribuição do Grupo de Trabalho 1 ao Primeiro Relatório de Avaliação Nacional do Painel Brasileiro de Mudanças Climáticas. Sumário Executivo GT1, PBMC, Rio de Janeiro, $24 \mathrm{p}$.

Salgueiro, J.H.P.B., Montenegro, S.M.G.L., 2008. Análise da distribuição espacial da precipitação na bacia do rio Pajeú em Pernambuco segundo método geoestatístico. Revista Tecnologia (UNIFOR) 29, 174-185.

Salviano, M.F., Groppo, J.D., Pellegrino, G.Q., 2016. Análise de Tendências em Dados de Precipitação e Temperatura no Brasil. Revista Brasileira de Meteorologia 31(1), 64-73.

Sausen, T.M., Marchiori, L.A.C, Batista, M.H., Faccin, A., 2018. Mapeamento de desastres naturais no Rio Grande do Sul para o período de 1985-2016. Revista Gestão e Sustentabilidade Ambiental, v. 7, n. esp., p. 268-303. DOI: $10.19177 /$ rgsa.v7e02018268302.

Silva, G., Silveira, C., Silva, M., Marcos Júnior, A., Souza Filho, F., Guimarães, S., 2020. Analysis of climate change projections on precipitation and temperature in Brazilian Hydrographic Regions for the 21st century. Brazilian Journal of Environmental Sciences (Online), 55(3), 420-436. https://doi.org/10.5327/Z2176-947820200624

Schuster, R. C., Fan, F. M.i, Collischonn, W., 2020. Scenarios of climate change effects in water availability within the patos Lagoon's Basin. RBRH, 25, e9. Epub February 10, DOI: https://doi.org/10.1590/2318-

0331.252020190061

Tejadas, B.E., Bravo, J.M., Sanagiotto, D.G., Tassi, R., Marques, D.M.L.M., 2016. Projeções de vazão afluente à lagoa Mangueira com base em cenários de mudanças climáticas. Revista Brasileira de Meteorologia 31(3), 262-272.

Teixeira, D.B. de S., Almeida, L.T., Ferreira, F.L.V., 2020. Tendências hidrológicas na bacia hidrográfica do rio Juquiá, São Paulo. Braz. J. Anim. Environ. Res., Curitiba, 3(2), p. 434-446. DOI: https://doi.org/10.34188/bjaerv3n2-003

Vieira, S.A., Osorio, D.M.M., Quevedo, D.M., Adam, K.N., Pereira, M.A.F., 2018. Metodologia de imputação de dados hidrometeorológicos para análise de séries históricas - Bacia do rio dos Sinos, RS, Brasil. Revista Brasileira de Climatologia 23(14), 189204. 
Vogel, R.M., Fennessey, N.M., 1994. Flow duration curves I: new interpretation and confidence intervals. J. Water Resources Planning Management 120(4), 485-504. 